\title{
USING DEONTIC MODALITY IN MAZE RUNNER (THE DEATH CURE) MOVIE
}

\author{
Muhammad Faisal $^{1}$, Chaidir Syahri ${ }^{2}$ \\ ${ }^{1}$ IKIP Siliwangi \\ ${ }^{2}$ IKIP Siliwangi \\ ${ }^{1}$ mhfaisal1610@gmail.com, ${ }^{2}$ syahri@ stkipsiliwangi.ac.id
}

\begin{abstract}
The objectives of this research are to identify the types of deontic modality and the meaning of utterances that found in The Maze Runner (The Death Cure) movie. This research used script only from the movie entitled The Maze Runner (The Death Cure) that had been analyzed by the researcher. The research used descriptive as a research design and qualitative method as a research methodology. Therefore, the data of this research was in the form of utterances that was performed by the cast in The Maze Runner (The Death Cure) movie. The research data were collected by taking the movie script from the internet. The collected data were analyzed by Saeed's theory. The finding revealed that there are two types of deontic modality found in utterances performed by the cast of The Maze Runner (The Death Cure) movie namely; Obligation and permission. The meaning of utterances that belongs to obligation means that someone have to do what the speaker said. While the meaning of utterances that belongs to permission means that someone's incumbency to authorized somebody else to do something.
\end{abstract}

Keywords: Deontic modality, The Maze Runner (The Death Cure), Semantics

\section{INTRODUCTION}

Semantics is a part of linguistics that connects meaning in language. Semantics is learning about meaning more deeply. Acording to Griffiths (2006: 1) in Rahmawati (2006) Semantics as one of the two main branches of linguistics, and it is basically the study of meaning. Talking about meaning in language, will be closely related to objects in linguistics itself such as: words, phrases, clauses, or sentences. Thus, in studying semantics, linguistic objects such as the structure of language and pronunciation are no longer needed. Katz (1972:1) in Telaumbanua (2010), added that "Semantics is the study that related to the sentence or the other linguistics object expresses, not with the structure with parts of syntactic or with their pronunciation of linguistic meaning". The similar statement came from Hornby (1972 : 789) in Ardino (2008), He defined "Semantics is branch of linguistics concerned with studying the meaning of words and sentences".

The purpose of this research is to identify that Maze Runner (The Death Cure) movie using deontic modality in the rest of conversation happened in this movie. Deontic modality shows whether the argumentation revealed by the sentence is compulsory or allowed based on some normative background such as law, morality, convention, etc. According to Saeed (2003: 136) in Winiharti (2017), deontic modals can convey two types of social knowledge, i.e. obligation and permission. Obligation is related to "what someone have to do something, whereas, permission related to 'someone's incumbency to authorize somebody else to do something. Modality is semantic category and it is very important to be understood. By understands of expressions' modal the speaker can know and evaluate a particular situation in the case of possibility, volition, necessity, probability, obligation and permission. Downing and Locke (1999: 382 - 383) in Vázquez Orta (2010) call these meanings as "basic modalities" and extend the basic concept by adding other notions such as: wish, desire, regret, doubt and usuality. In 
other words, all the above stated, ideas cover the subjective manner or declaration of the speaker, who provides her/his personal idea and correlation with reality.

In deontic modal sentences, the speaker or statement maker of an obligation or a permission is not always supposed to the speaker. It may be issued by some other person, institution, law, moral code, and so forth. Consequently, with deontic modal sentences anyone can give the sign that related to obligation, or permission in a conversation or utterance. Saeed (2003: 136) gives several sentences that related to obligation and permission in deontic modal are as follows:

\section{Obligation}

Obligation is concerned with "what someone have to do.

Examples:
a. I must call her.
b. I have to get in touch with her.
c. I need to leave a message.
d. I ought to ring her.
e. I should call anyone else.

Must, have to, need to, ought to, and should are all obligations.

\section{Permission}

Permission related to 'someone's incumbency to authorize somebody else to do something. Examples:
a. You can have these postcards for free.
b. You could have these postcards for free.
c. You may have these postcards for free.
d. You might have these postcards for free.

Can, could, may, and might are all permissions.

The researcher was analyzed of using deontic in written conversation that has been done by some researchers. Firstly, (Naghizadeh \& Deriss, 2015) carried out research entitled "The Role of Intended Audience in Determining Modality Type: A Study in Relation to The Iran Constitution". This research is analyzed and different types and subtypes of modals are distinguished in the text of Iranian Constitution. Secondly, (Hariri, 2004) held a study " $A$ Review of Deontic Modality in Indonesian Language Based on The Theory of Japanese Modality". Thirdly, "Scaling Deontic Modality in Parliamentary Discourse" by (Milica Vuković Stamatović, 2016). From all of the relevant research above, the previous researcher only analyze some parts of the deontic modality. In this research, the researcher wants to analyze deontic modality that contained in Maze Runner (The Death Cure) Movie.

\section{METHOD}

This research used descriptive qualitative method, because the implementation includes the data, analysis, and interpretation of the meaning of the data obtained. As stated by Perry (2005, cited in Dewi, Hernawan, Apsari, 2019) that qualitative research is characterize by the verbal description of its data. In addition, according to Arikunto (2010:137) in (Irawan \& Andriani, 2018), "the descriptive method is a method of describing the state of an event object to infer applies, in general, to solve a problem by gathering the data, sort or classify". In collecting the data the researcher watched Maze Runner (The Death Cure) movie to get the comprehension more deeply about the movie itself after that, the researcher read some resources about deontic 
from the internet so that the researcher would be understand about the deontic's role especially in obligation and permission by speaker's utterance. Then, the data was analyzed by using Saeed's theory. The researcher categorized the deontic modality into two types namely; Obligation and Permission as proposed by Emilia (2008 cited in Apsari, 2018).

\section{RESULTS AND DISCUSSION}

\section{Results}

The results shown that Maze Runner (The Death Cure) uses deontic modals in several conversation in the rest of movie. The researcher found some sentences that a speaker has been spoken to the hearer that related to deontic modals. According to Saeed (2003: 136) in Winiharti (2017), deontic modals can convey two types of social knowledge, i.e. obligation and permission. Obligation is concerned with 'what someone have to do whereas, permission related to 'someone's incumbency to authorize somebody else to do something. The researcher found several sentences contained words belong to deontic modals, such as: need, have, can, might and should. For more detail the researcher will present the following Table 1 below:

Table 1. The Uses and Meanings of Deontic Modals in Maze Runner

\begin{tabular}{|c|c|c|}
\hline Modal Verbs & Meanings & Deontic \\
\hline Need & Obligation & $\begin{array}{c}\text { You need to go right } \\
\text { now! }\end{array}$ \\
\hline Have & Obligation & $\begin{array}{c}\text { We just have to make } \\
\text { sure. }\end{array}$ \\
\hline Can & Permission & $\begin{array}{l}\text { I can help with that. } \\
\text { Follow me! }\end{array}$ \\
\hline Might & Permission & $\begin{array}{c}\text { There might be a way } \\
\text { now }\end{array}$ \\
\hline Should & Obligation & $\begin{array}{c}\text { There is one thing you } \\
\text { should know. }\end{array}$ \\
\hline
\end{tabular}

\section{Discussion}

On the basis of research finding and the result of analysis of Maze Runner (The Death Cure) movie used deontic modality in the rest of conversation that occured in the movie. Modality is a speaker's manner toward the subject matter of the topic of conversation or utterance. According to Saeed (2003: 135) in Winiharti (2017) argues that modality is a general terms are used as a tool for the speaker to express various levels of commitment to, or belief in, what the speaker says. It is supported by Cruse (2004: 298) in Winiharti (2017) that stated, "Modal expressions are those which signal a particular manner on the section of the speaker or statement maker to the argumentation expressed or the situation illustrated." It is usually expressed in modal verbs such as: have to, must, will, can, may and should. The researcher provided some sentences that will be discussed as follows:

According to Saeed (2003: 136) in Winiharti (2017), deontic modals can convey two types of social knowledge, i.e. obligation and permission. Obligation is related to "what someone have 
to do something whereas, permission related to 'someone's incumbency to authorize somebody else to do something. Refers to the Table 1 above, namely:

a. You need to go right now! (Need used for expressing obligation) Deontic reading or hearer: We are under obligation to go right now.

b. We just have to make sure. (Have used for expressing obligation) Deontic reading or hearer: We are under obligation to make sure.

c. I can help that. Follow me! (Can used for expressing permission) Deontic reading or hearer: He asks for permission to follow him.

d. There might be a way now. (Might used for expressing permission) Deontic reading or hearer: He asks for permission to give an information.

e. There is one thing you should know. (Should used for expressing obligation) Deontic reading or hearer: We are under obligation to know something.

\section{CONCLUSION}

Based on the results of the research, the researcher divided his conclusions as follows:

1. The purposes of this research was identified the sentences or utterance that contained in the script of the movie and to classify the deontic modals and the meaning from the sentences itself based on the theory of Saeed (2003).

2. Deontic modals forms that was found in the Maze Runner (The Death Cure) appropriate with Saeed's statements on obligation and permission, like:

-Obligation: need, have, should.

-Permission: can, might.

Obligation is related to 'what someone have to do, whereas, permission related to 'someone's incumbency to authorize somebody else to do something.

\section{ACKNOWLEDGMENTS}

This work would not have been possible without the financial support from the English Department, Language Faculty, IKIP Siliwangi. I am especially indebted to Ibu Ida Lisdawati, M.Hum and Bapak Chaidir Syahri, M.Pd my lecturer of the English Department of IKIP Siliwangi. They have given me lot of good scientist. I am grateful to those with whom I have had the pleasure to work on this issue. My special thank due to Chairman of English Department, Pak Yana M.Hum. I would also like to thank my parents whom I love most, they support me always in everything. I would like to thank to anyone that their names are not mentioned here one by one.

\section{REFERENCES}

Apsari, Y. (2018). Reflective Reading Journal In Teaching Writing. Indonesian Efl Journal, 4(2), 39-47.

Ardino, R. T. (2008). An Analysis Of Figurative Expressions Found In Enrique Iglessias ' S Selected Songs Lyrics.

Dewi, M. W., Hernawan, K. F., \& Apsari, Y. (2019). Thematic Progression In Students'descriptive Texts. Project (Professional Journal Of English Education), 2(2), 227-233.

Hariri, T. (2004). A Review Of Deontic Modality In Indonesia Language Based On The Theory Of Japanese Modality. (September).

Irawan, R., \& Andriani, D. (2018). An Analysis Of Educational Values Of N Ovel “ Maze R 
Unner " By. 3(1), 38-50.

Milica Vuković Stamatović. (2016). Scaling Deontic Modality In Parliamentary Discourse. Researchgate, (November), 20.

Naghizadeh, M., \& Deriss, F. (2015). The Role Of Intended Audience In Determining Modality Type: A Study In Relation To The Iranian Constitution. 3, 87-93.

Olaniyan, K. K., Adeolu, \& Adeniji. (2015). Modality In Statement Of Objectives In ArtsBased Research Article Abstarcts. Journal, British Vol, English Linguistics Centre, European Uk, Development, 3(1), 42-51.

Rahmawati. (2006). A Semantic Analysis Of Entailment In The Da Vinci Code Movie.

Telaumbanua, V. A. (2010). An Analysis Of Figurative Expressions Found In Ecclesiastes Thesis By: Vita Amelyana Telaumbanua Faculty Of Letters. (070705038).

Vázquez Orta, I. (2010). A Contrastive Analysis Of The Use Of Modal Verbs In The Expression Of Epistemic Stance In Business Management Research Articles In English And Spanish. Ibérica, 19(2010), 77-96.

Winiharti, M. (2017). The Difference Between Modal Verbs In Deontic And Epistemic Modality. Humaniora, 3(2), 532. Https://Doi.Org/10.21512/Humaniora.V3i2.3396

Springfieldspringfield. (2018). Maze Runner: The Death Cure (2018) Movie Script. Retrieved From Https://Www.Springfieldspringfield.Co.Uk/Movie_Script.Php?Movie=MazeRunner-The-Death-Cure 